\title{
Physical activity by children: an analysis based on Social Network Theory
}

\section{Actividad física en escolares: un análisis desde la Teoria de redes sociales}

\author{
Alejandra Mota-Cervantes ${ }^{1}$, Edgar Leonel González-González ${ }^{1}$, Santiago Andrés Henao-Morán ${ }^{1}$, \\ Jessica E. Moreno-Saracho', Guadalupe Rodríguez-Oliveros ${ }^{1}$
}

\begin{abstract}
Suggested citation: Mota Cervantes A, González González EL, Henao Morán SA, Moreno Saracho JE, Rodríguez Oliveros G. Physical activity by children: an analysis based on Social Network Theory. Rev Univ Ind Santander Salud. 2016; 48(4): $436-445$. DOI: http://dx.doi.org/10.18273/revsal.v48n4-2016002 (c) (i)
\end{abstract}

\begin{abstract}
Introduction: Physical inactivity is a risk factor for obesity and non-transmissible chronic diseases; this represents a burden for health services and limits the development of social capital. Objective: To identify the structure of the school and the community social network for the practice of structured and unstructured physical activity (PA) by schoolchildren. Methods: Cross-sectional study based on Social Network Theory conducted in Morelos, Mexico. A convenience sample of 33 children aged 8 to 10 years-old was selected from two public elementary schools. PA evaluations through pedometry, anthropometric assessments, and PA social network assessments (size, density, homophily, and centrality of actors) were performed. Results: The overall PA network was composed by 239 actors that were mostly peers $(40.2 \%)$. The school sub-network had an average of 122 actors $(87.0 \%$ children/peers and $13.0 \%$ teachers). Most children conducted PA in groups with their peers; overweight/obese children (mostly girls) lingered in the periphery of the school sub-network. The community sub-network had an average of 160 actors (55.0\% parents/family members, $41.2 \%$ children/peers, and $3.8 \%$ Soccer-coaches). This sub-network, composed mostly by men $(60.6 \%)$, was highly fragmented (19 sets of actors); they generally promoted unstructured "masculine" activities. The girls who did not perform structured PA and did not meet the recommended number of steps/day were in isolated and small community networks. Conclusions: School teachers are key actors in promoting structured PA. Male peers stand out as promoters of unstructured activity in the school and the community. Overweight and obese girls are a vulnerable group by having fragmented social networks. Public health interventions based in social networks should empower girls motor activity and adult women to become prestige leaders for promoting PA among children.
\end{abstract}

Keywords: physical activity, social neworking, children, health promotion, obesity.

\section{RESUMEN}

Introducción: La inactividad física es factor de riesgo para desarrollar enfermedades crónicas no transmisibles como la obesidad, limitando el desarrollo del capital social. Objetivo: Identificar la estructura de las redes sociales escolar y comunitaria para la práctica de la actividad física (AF) en escolares. Métodología: Estudio transversal basado en la Teoría de redes sociales, realizado en escuelas primarias públicas de Morelos, México, en 33 niños de 8

1. Instituto Nacional de Salud Pública. Cuernavaca, Morelos, México.

Correspondence: Guadalupe Rodríguez Oliveros. Address: Instituto Nacional de Salud Pública. Centro de Investigaciones en Salud Poblacional. Av. Universidad 655. Col. Santa María Ahuacatitlán. Cuernavaca, Morelos, México. E-mail: guadalupe.rodriguez@insp.mx Telephone: +52 (777)329 3000 Ext 5113 . 
a 10 años de edad. Se realizaron mediciones de AF estructurada y no estructurada mediante podometría, evaluaciones antropométricas y de la estructura de las redes sociales de los escolares (tamaño, densidad, homofilia, y centralidad). Resultados: La red general incluyó 239 actores, la mayoría (40.2\%) pares de los escolares. La sub-red escolar incluyó 122 actores, 87.0\% escolares/pares y 13.0\% maestros. Las niñas con sobrepeso/obesidad se ubicaron en la periferia de la sub-red; la mayoría de los escolares realizaron AF grupal con sus pares. La sub-red comunitaria incluyó 160 actores (55.0\% padres/otros familiares, 41.2\% escolares/pares y 3.8\% entrenadores de futbol). Esta sub-red estuvo altamente fragmentada (19 conjuntos de actores), con $60.6 \%$ hombres promotores de actividades no estructuradas "masculinas". Las niñas sedentarias y que no realizaban AF estructurada formaron redes pequeñas y aisladas. Conclusiones: Los maestros y pares de sexo masculino son actores clave en la promoción de AF en la escuela y la comunidad. Las niñas con sobrepeso/obesidad son un grupo vulnerable al tener redes fragmentadas. Intervenciones de salud pública basadas en redes sociales, deben empoderar a niñas y mujeres para convertirse en líderes promotoras de AF en escolares.

Palabras clave: Actividad física, red social, niños, promoción de la salud, obesidad.

\section{INTRODUCTION}

Insufficient physical activity (PA) is a risk factor for becoming overweight or obese, and for developing non-transmissible chronic diseases ${ }^{1,2}$, this limits the development of social capital and represents a burden for health services worldwide ${ }^{3,4}$. For example, $48.0 \%$ of schoolchildren over 10 years of age in Mexico are inactive; that is, they perform less than four hours per week of moderate and/or vigorous physical activity ${ }^{5,6}$. This prevalence is higher than the one reported for Latin America (43.2\%) in population older than 14 years-old ${ }^{5}$.

The World Health Organization recommends developing and implementing health promotion policies and programs that aim to increase PA among schoolchildren. These would include the strengthening of social networks that promote both structured and unstructured $\mathrm{PA}^{7}$. Social networks are sets of relationships that directly or indirectly link individuals (actors) and organizations to achieve common goals by performing different activities, exchanging information, and providing social support ${ }^{3}$. In this regard, there is compelling evidence showing that relationships among the actors or members of social networks are determined by the setting or context they interact in, as well as by individual characteristics, among other factors ${ }^{8,9}$.

According to Social Networks Theory, four indicators are relevant for determining the structure of social network: ${ }^{10-12}$ the network size and density, as well as the homophily and the centrality of actors. The network size is the number of members of the social network, the density refers to the proportion of existing relationships versus the total possible relationships for performing a behavior, the homophily is the probability that individuals with similar demographic characteristics perform a behavior together, and the centrality is the position of the actors in the social network, according to their degree of prestige, influence, and intermediation (bridge actors).

In the school setting, the practice of PA by children can be positively or negatively influenced by social networks in which peers, teachers, school authorities, government representatives, members of civil society, and the family participate ${ }^{13}$. Identifying the type of actors involved in the children's social networks and how they relate to each other, is important for the design of interventions that are aimed at individuals and groups to help promote PA at schools and in the community ${ }^{14,15}$.

Few studies have been conducted to explore the relationship between social networks of schoolchildren and the practice of $\mathrm{PA}^{16}$, while there are some studies conducted in adolescents ${ }^{17-20}$. Moreover, little research has been done to identify differences and key actors of Hispanic children's social networks in different contexts or settings ${ }^{21,22}$. Therefore, the aim of this study is to identify the structure of the social networks pertaining to the practice of structured and unstructured PA by Mexican children, in both the school and the community contexts. Specifically this study aims to explore the size and density of the PA social networks, as well as the homophily and the centrality of actors, including their degree of prestige, influence, and intermediation.

This study provides evidence relevant for the development of network-based strategies to promote PA in schoolchildren, representing a promising avenue to strengthen traditional public health interventions aiming to prevent childhood overweight and obesity in Hispanic populations ${ }^{23}$. This study is also useful to program planners to inform future interventions aiming to empower girls and adult women for promoting PA among children. 


\section{MATERIAL AND METHODS}

\section{Study Design, Location and Sampling}

A Cross-sectional, observational, and descriptive study based on Social Network Theory was conducted in the semi-urban area of Tlaltizapan, Morelos, located in Central Mexico. A convenience sample of 33 children of both sexes (17 girls and 16 boys), aged 8 to 10 years-old, and from 4th and 5 th grade was selected from two public elementary schools of the same school District ${ }^{24}$.

\section{Data Collection}

Data collection included a social networks assessment, a PA evaluation, and an anthropometric assessment of the children, described as follows.

Social Networks Assessment. The individual or egocentric PA network of each of the students was assessed to determine the size of the network and the actors that were present in more than one network ${ }^{25}$. A questionnaire composed by 41 items was used for collecting social network data. The inquiry topics focused on exploring the following issues regarding PA in both the school and the community contexts: a) the key persons or actors related to children in practicing PA, b) the socio-demographic characteristics (gender, age, and family relationships) of the children and the members of the social network, c) the type of PA (structured and non-structured) performed by children, and d) the traveling time and mode of transportation used by children on a typical day during the week. A pilot test of the questionnaire was performed in an elementary school located in the research setting, and further adjusted considering local terms. The questionnaire was administered individually to the children at the school by a trained nutritionist.

Physical Activity Evaluation. The level of physical activity was evaluated through pedometry. The number of steps performed by the children during three consecutive week-days was recorded using a pedometer New-Lifestiles Inc. brand, model NL1000. The children wore a pedometer on their hips, at the height of their iliac crest. They removed the device only to bathe, sleep, or swim. On a daily basis, three times during school hours, trained personnel registered the number of steps from the pedometer. The first lecture was made at 8:00 AM, when school time started. The second lecture was made at 1:00 PM, when regular school time ended, and the third lecture was made at 4:00 PM, after finishing extended school time. The steps performed by children outside the school were estimated by the difference between the last lecture of the school time and the first one of the next morning.

Anthropometric Assessment. To determine the nutritional status of children, we used electronic scales SECA brand, with $100 \mathrm{~g}$ accuracy and stadiometers up to $1 \mathrm{~mm}$ precision. Standard procedures for measuring weight and height were performed by trained research assistants, according with the technique described by Habitch $^{26}$.

\section{Data Analysis}

To perform the analysis of the PA social networks ${ }^{10-12}$, the four indicators describ above described were used: a) network size, the actors (nodes) related to children in practicing PA both at the school and the community; b) network density, the number of actors to whom each member of the social network was linked on average; c) homophily the probability of practicing PA among children with similar characteristics such as age, sex, or nutritional status, and d) centrality of actors, defined according to three characteristics: prestige, influence, and intermediation of the actors. The actors with the greatest "prestige" were those more frequently mentioned by the children; the actors who were "more influential" had a larger number of direct contacts with other actors; and the actors with a "high degree of intermediation" were those who support PA by acting as bridges for individuals in the social network. These indicators were determined in regards to the practice of both structured and unstructured PA in the two studied contexts. Structured PA included scheduled exercises during physical education classes, sports training, and dance; unstructured PA included games, recreational activities, commuting, and traveling around the community. Similarly, the structure of the PA school and community sub-networks was determined by using the same indicators described above $^{27-28}$. The UCINET 6.314 was used to perform the social networks analysis.

Statistical Analysis. The socio-demographic characteristics at the actors at the school and the community PA social networks, the average steps/day of the children, and their body mass index (BMI) were analyzed using descriptive statistics and non-parametric statistics with the Mann-Whitney test.

For the nutritional status assessment, the BMI for age indicator of the World Health Organization 
reference was used. The cutoff point established for the classification of overweight +1 standard deviation (SD) and +2 SD for obesity ${ }^{29}$.

The compliance of children with the recommendations for PA was evaluated by comparing the number of average steps performed daily by the children with the number of steps recommended per day for their age, which are 12,000 steps/day for girls and 15,000 steps/day for boys, between 6 and 12 years of age ${ }^{30}$. The children were classified into two categories: active and inactive. Active children were those who met the recommendations for PA, while inactive children were those who did not meet the recommendations. The statistical calculations were performed with the STATA 11.2 software.

Graph Analysis. The PA social networks of the school and community contexts were graphically represented using the Spring Embedder technique ${ }^{31}$. The sizes and shapes of the graphs indicate the characteristics of the children: age, sex, nutritional status, and compliance with the PA recommendation. The NetDraw 2.111 software was used to create the graphs.

\section{RESULTS}

This section reports the structure, size, and density of the overall children's PA social network, as well as the social sub-networks of both the school and the community contexts. Homophily and centrality of the actors participating in the children's social networks are also reported.

\section{Characteristics of the study sample}

The median age of the children was 9 years old (IQR $9,10), 51.5 \%$ were girls, $64.7 \%$ of whom had a normal nutritional status, and $35.3 \%$ were overweight or obese. Of the boys, $75 \%$ had a normal nutritional status and $25 \%$ were overweight.

Figure 1 shows that $29.4 \%$ of girls and $18.7 \%$ of boys did not meet the recommended number of steps/day for their age. No statistically significant differences in meeting the recommendation for PA were found by sex $(p=0.5)$ or nutritional status $(p=0.2)$. A total of $81.2 \%$ of boys and $64.7 \%$ of girls referred walking for commuting; the median walking time was 14 minutes daily (IQR 10, 30).

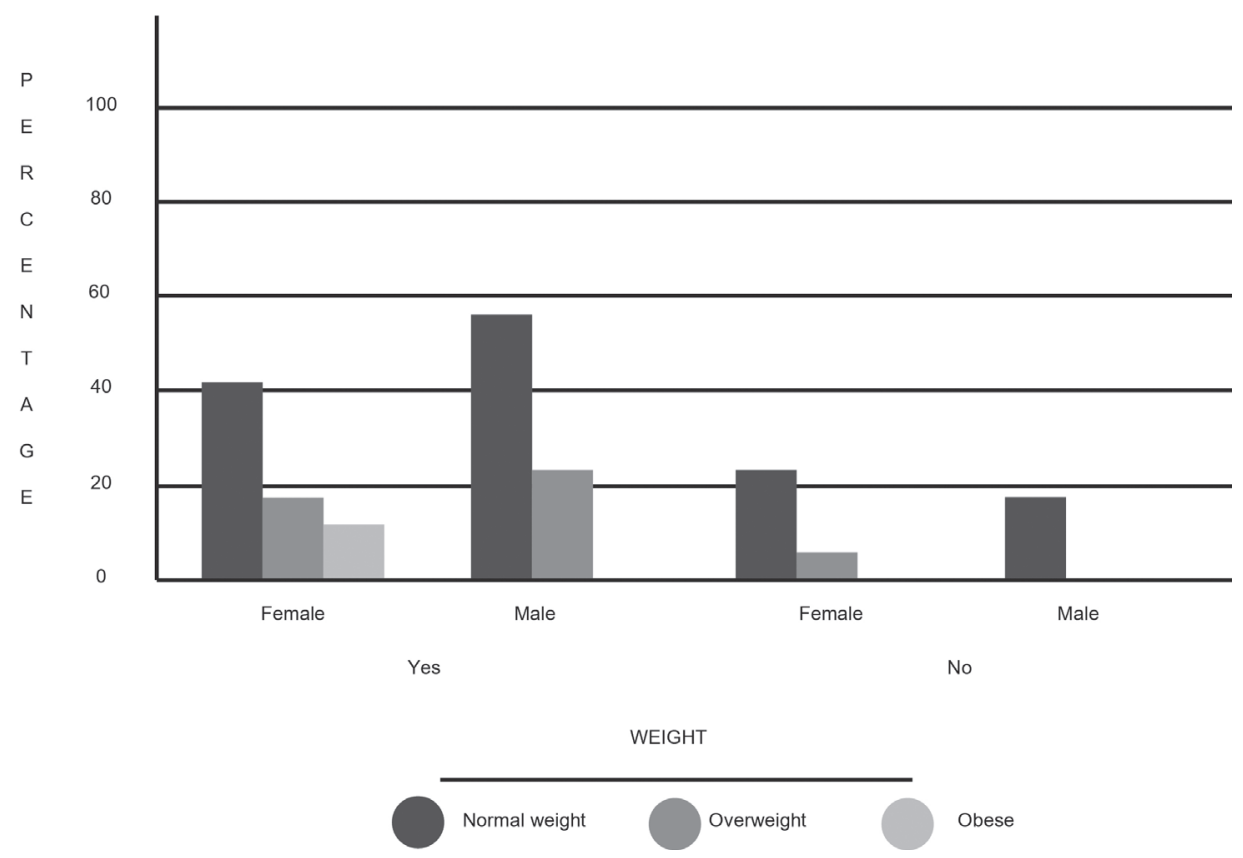

Figure 1. Percentage of schoolchildren who meet the recommendation of steps for age according to sex and nutritional status

The primary PAs practiced by the children in the schools were sedentary group activities (board games), and moderate to vigorous activities (dodgeball, soccer, dance, and physical education classes). In the community context, they performed activities with different levels of intensity and degrees of structure. Unstructured activities were board games and soccer, and structured activities were soccer, limalama, bicycling, and physical education classes. A total of $88.2 \%$ of girls and $56.2 \%$ of boys indicated not practicing structured PA. 


\section{Social networks pertaining to PA by children}

Table 1 shows the size of the overall PA social network that was composed by 239 actors (nodes), their median age was 10 years old (IQR 9, 11) and most of them were male $(55.2 \%)$. This social network included mostly peers $(40.2 \%)$, and family members $(27.6 \%)$, as well as schoolchildren, parents, teachers, and soccer coaches.

Table 1. Demographic characteristics of the actors in the school and the community social networks.

\begin{tabular}{lcccc}
\hline \multicolumn{1}{c}{ Type of Actor } & $\boldsymbol{n}^{*}$ & $\begin{array}{c}\text { Total } \\
\%\end{array}$ & $\begin{array}{c}\text { Male } \\
\%\end{array}$ & $\begin{array}{c}\text { Age Median } \\
(\mathbf{p 2 5}-\mathbf{p 7 5}) * *\end{array}$ \\
\hline $\begin{array}{l}\text { School } \\
\quad \text { Children }\end{array}$ & 33 & 13.8 & 48.5 & $9(9-10)$ \\
$\quad \begin{array}{l}\text { Peers } \\
\text { Teachers }\end{array}$ & 73 & 30.6 & 45.2 & $9(9-10)$ \\
Community & 16 & 6.7 & 62.5 & $30(30-53)$ \\
$\quad$ Family members & 66 & 27.6 & 60.6 & $8(4-12)$ \\
$\quad$ Peers & 23 & 9.6 & 60.9 & $9(8-11)$ \\
$\quad$ Parents & 22 & 9.2 & 59.1 & $35(29-38)$ \\
$\quad$ Coaches & 6 & 2.5 & 100.0 & $46(32-70)$ \\
Total & 239 & 100.0 & 55.2 & $10(9-11)$ \\
\hline
\end{tabular}

$*_{n=}$ sample size

$* * p=$ percentile

\section{Social sub-network in the school}

The school PA sub-network was composed by 122 actors, including children and peers $(87.0 \%)$ of which $54.0 \%$ were boys, and teachers $(13 \%)$, of which $62.5 \%$ were male. The median age of the actors was 9 years old (IQR 9, 10).

Figure 2 shows the school PA sub-network as a single network joined by one bridge actor (physical education teacher). The density of the school sub-network was $3.1 \%$, which indicates that each member was linked with four actors, on average. The children with the highest centrality values met the recommended number of steps/day for their age, in contrast to those on the periphery of the social sub-network. The children with overweight and obesity (mostly girls) were identified to be located near each other, primarily in the periphery of the social sub-network. Located at the center of the social sub-network were the actors with the most prestige in organizing structured PA in the schools: two physical education teachers and a dance teacher. The most influential actors were children two boys and a girl who performed unstructured PA. The actors with the largest degree of intermediation (bridge actors), were two physical education teachers and a boy. With respect to the homophily indicator, the children practiced PA with their partners who were mostly actors of the same sex (-0.49) and similar ages $(-0.28)$.

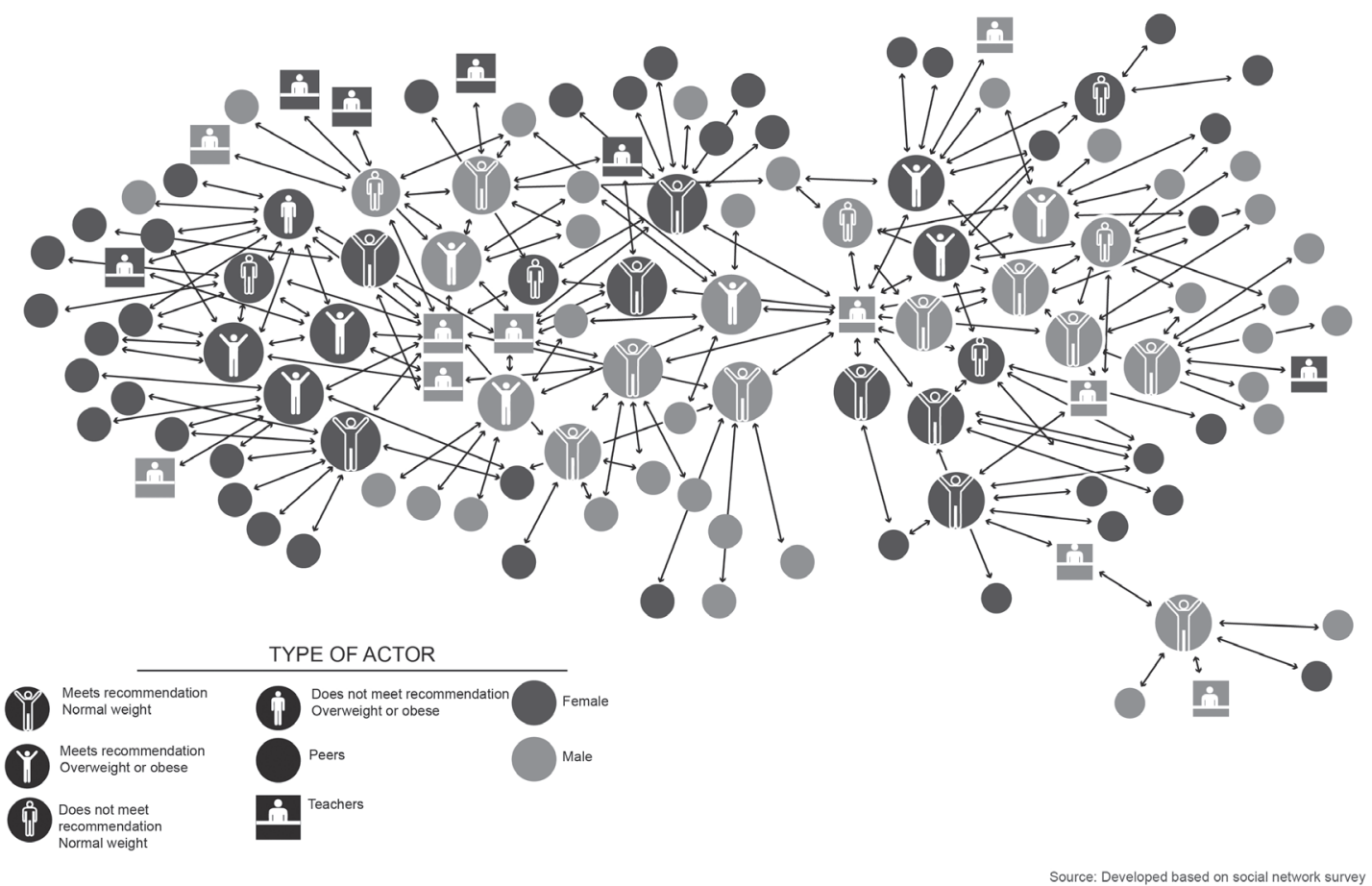

Figure 2. Social sub-network corresponding to physical activity of schoolchildren in the school context 


\section{Social sub-network in the community}

The social sub-network in the community was composed of 160 actors, including $41.2 \%$ family members, $20.6 \%$ schoolchildren, $20.6 \%$ peers, $13.8 \%$ parents, and $3.8 \%$ Soccer coaches. A total of $60.6 \%$ of the members were male, and their median age was 11 years old (IQR 6, 15).

Figure 3 shows this social sub-network as being highly fragmented while it was composed by 19 sets of actors. The most numerous set included children who practiced structured PA, primarily soccer training. Most of these children met the recommended number of steps/day for their age. Children who did not perform structured PA, as well as children who did not meet the recommended number of steps were in smaller social networks that were independent from each other; the majority of girls were found in these networks.
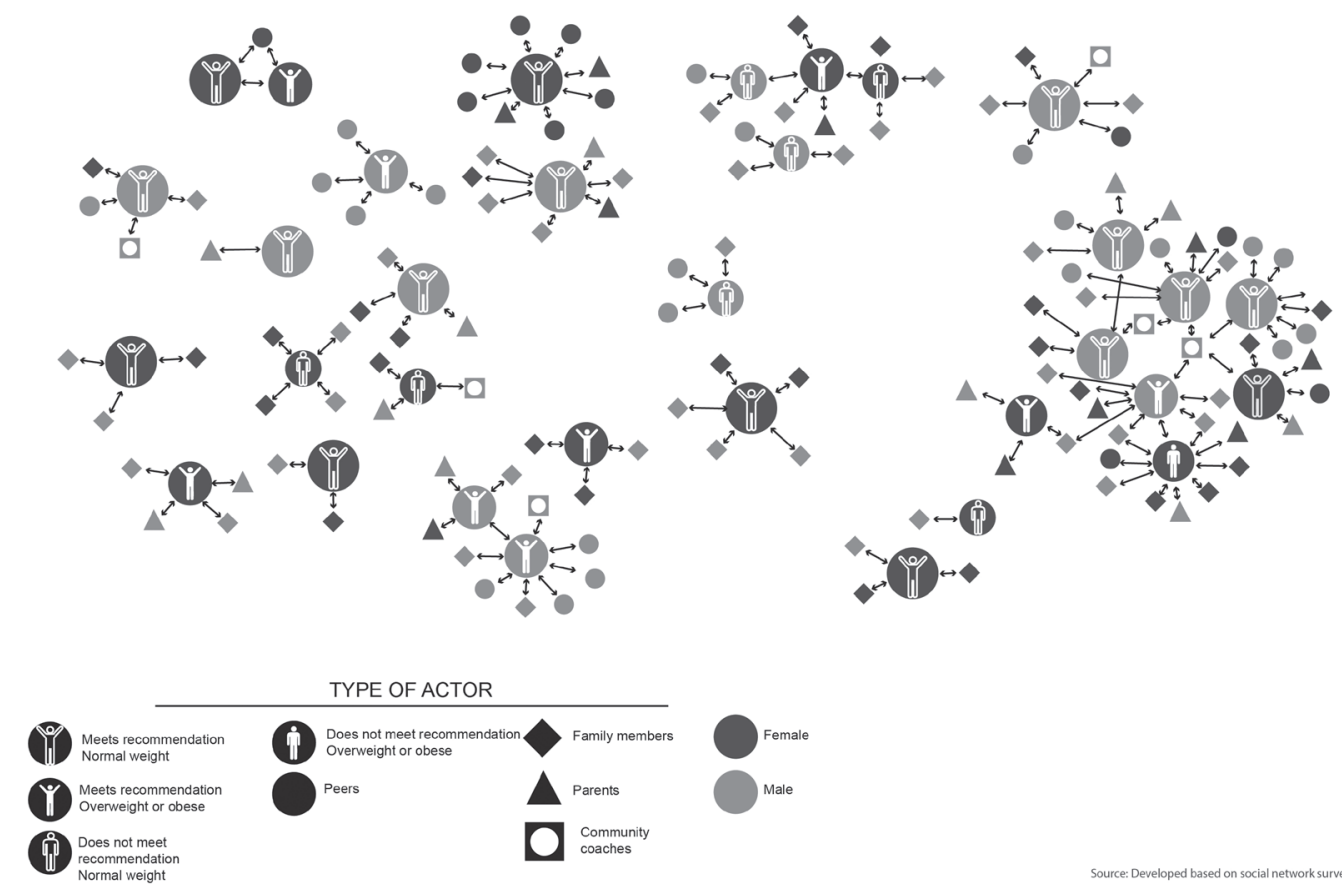

Figure 3. Social sub-network corresponding to physical activity of schoolchildren in the community context

The density of the community sub-network was $1.1 \%$, which indicates that each member was linked with two actors, on average. The actors with the greatest degree of prestige, influence, and intermediation for organizing structured PA, were Soccer coaches, and for organizing unstructured PA were children. With respect to the homophily indicator, the schoolchildren performed PA in the community mostly with children of the same sex $(-0.34)$.

\section{DISCUSSION}

This study herein presents the structure of social networks pertaining to the practice of structured and unstructured PA by schoolchildren in order to provide evidence of the actors and contexts that are relevant to promoting PA in this age group. Our study shows that children preferred to practice PA in groups with their peers, teachers, coaches, and that family members were key factors in promoting PA in the school and the community. Girls were a vulnerable group, particularly those that were overweight and obese, since they formed fragmented networks lacking actors to promote PA. Children performed unstructured PA mostly in the community and structured PA mostly in the school.

Schoolchildren and same-sex peers were the primary members of both the school and community social networks, as shown by the homophily indicator. This is consistent with findings by Coppinger ${ }^{32}$ which indicate that peers are relevant key players influencing the practice of PA by schoolchildren ${ }^{33}$.

Children in both contexts were related to actors who promoted structured and unstructured activities of different intensities (sedentary to vigorous activities). In this study, few actors promoted structured PA, particularly in the community context. 
Among the promoters of structured PA, the teachers and the Soccer coaches had the greatest degree of prestige and intermediation in the children's PA social networks. Similar findings resulted from a study conducted in Canada were it was found that by involving adult leaders in the promotion of PA the amount of time children spend performing these activities increased, as long as the leaders had the necessary competencies for instructing the children ${ }^{34}$.

It is worth mentioning that most of the actors who promoted both structured and unstructured PA were male, who generally organized sports activities considered to be "masculine" in Latin America, such as soccer" ${ }^{35}$. Male peers stood out in our study as promoters of unstructured activity in the school and the community. This may explain the gender differences found among the children's social networks in meeting the recommended number of steps/day, in which girls had significantly lower values than boys. This has a negative implication that reinforces the vulnerability of girls with overweight or obesity, because the few promoters available in the community is likely to promote activities only for men ${ }^{16}$.

A relevant finding is the lack of mothers and other female family members in practicing unstructured PA with children in the community context. This finding stresses the need for developing communitybased interventions that aim to increase social capital through the participation and engagement of mothers, and other female relatives in the promotion of PA. In Mexico, gender-oriented interventions in this regard may be delivered through the National Agreement for Healthy Nutrition (Acuerdo Nacional para la Salud Alimentaria; ANSA, Spanish acronym) ${ }^{36}$ and other social development and health initiatives.

Among the unstructured activities, our study identified walking as the primary mode of travel, and closeness to schools as a key factor in choosing these means. These results are consistent with the studies of Panter $^{37}$ and Murtagh ${ }^{38}$ who reported that elementary students with low socio-economic status performed active transportation (walking) in urban settings, when their families perceived they would travel in a safe environment.

Gender issues were evident in this study; for example, participation in moderate or vigorous PA was greater for boys than for girls. These findings are consistent with other studies that show gender differences among schoolchildren in performing $\mathrm{PA}^{39-41}$. Additionally, in the community sub-network, girls were observed to have fragmented networks composed of a few actors; these social dynamics could limit PA options and the capacity of girls for meeting the recommended number of steps/day for their age. Moreover, overweight and obese girls did not meet the recommended number of steps/day for their age. The lack of social support from adults and peers for overweight girls can negatively affect the practice of PA, as indicated by a study performed by Gesell ${ }^{22}$. In this regard, modeling and vicarious processes are the fundamental means by which children's behavior is acquired and existing patterns may be modified driving self-efficacy for $\mathrm{PA}^{42,43}$. Accordingly, overweight girls prefer to socialize among themselves and perform sedentary activities, unlike boys who create large networks, primarily for soccer training, as shown in this study. Considering the high rates of obesity in Hispanic children these findings highlight the importance of empowering schoolgirls by interconnecting their fragmented social networks, and by expanding and strengthening current social networks with supplementary influential and prestige actors.

A confirmatory finding was that the children preferred to practice light or vigorous PA in groups with their peers both in the school and the community. Several studies have demonstrated the influence that siblings and friends have in children's PA behaviors ${ }^{11,16,18,19,21}$. In this regard, the study by Macdonald-Wallis reports that schoolchildren with similar PA patterns had social networks composed by their peers ${ }^{13}$. Therefore, the social networks approach focused on peer social support acting as a promissory theoretical framework for the design of interventions to promote PA in children.

The structure of the social network in the school context was smaller, but less fragmented and had a greater density than that of the community context, indicating greater cohesion among the actors. This supports the conclusions presented by a systematic review and a meta-analysis, which showed the effectiveness of school interventions ${ }^{23,44}$. These findings highlight the importance of targeting interventions to elementary schools to promote both structured and unstructured PA. In addition, no links were observed in the community network between municipal authorities responsible for fostering PA and schoolchildren, indicating a lack of engagement and eventually, lack of coordination among these key actors. This limits opportunities for structured activities aimed at children, since none of the municipal health, education, sports promotion, or social wellbeing authorities were identified as promoters of PA in the social networks of children ${ }^{15}$. Several public health 
programs have tried to implement mechanisms to foster community participation to encourage healthy lifestyles. However, the limited success of these interventions depends largely on the capacity and sense of ownership of those responsible of the program's implementation, as well as of the support and willingness of the local authorities ${ }^{45}$.

The generalization of our results may be somehow limited by the population and the contexts of the study. Cultural factors could have influenced our results to some extent; for example, gender-related findings from this study may be different in non-Hispanic populations sharing different cultural values. We studied two relevant contexts for PA in a semi-urban area; however our understanding of the children's PA social networks could be improved if we would have studied the home setting and rural areas. Some potential limitations of the study design concerning sampling would be offset by the use of an egocentric network approach which postulates that the most significant interpersonal relationships are those that are established with family, friends, neighbors, and peers ${ }^{27}$, as was explored in this study. Finally, a more comprehensive understanding of the children's PA network would be achieved by including a qualitative component and by studying factors not fully considered such as the distance between the school and home and the physical environment.

It is worth highlighting the mixed approach of this study, which combined the social networks analysis with an objective and reliable quantitative PA measurement such as pedometry and anthropometry. This provides and advantage over self-reported information about PA and self-reported weight and height. Additionally, this study documented PA social networks in regards to different types of activities performed in two different contexts which allowed having a more comprehensive and solid perspective of the schoolchildren social networks.

In conclusion, the structure of the children's social networks pertaining to the practice of PA in the school context was cohesive for boys and fragmented for overweight and obese girls. The primary PAs practiced by children in the schools were sedentary group activities. The most influential actors at school were children who practiced structured PA in groups with their peers. Children performed unstructured PA mostly in the community by forming fragmented networks. Soccer coaches had the greatest degree of prestige, influence, and intermediation in the community. Female participation in PA at the community level was limited.
Our findings pointed out the need of implementing network-based interventions to promote the practice of PA in schools and the communities, particularly in those settings where girls and adult women are not fully participating. Sound interventions should include a gender-oriented component aiming to empower adult women, such as mothers and female teachers, to become prestige leaders in the children's social networks. Additional efforts must be given to raise the awareness of teachers, coaches, and other key stakeholders about the importance of fostering PA strategies targeted to overweight girls. Local authorities should also improve coordination with other community stakeholders in order to make available spaces for children, and particularly for girls to practice structured and unstructured PA.

\section{ETHICAL CONSIDERATIONS}

Approval to perform the study was requested from local authorities and school principals. To inform the objectives, procedures, and ethical considerations of the project, two meetings were held in each school, with 4th and 5th grade children and their parents, respectively. Written parental consent and verbal informed agreement from the children for their participation in the study were obtained. Data collection was conducted in the presence of the parents on the day and time jointly agreed upon by them and the teachers. The study was approved by the Ethics, Research and Biosafety Committees of the National Institute of Public Health (INSP, Spanish acronym). The participants did not receive incentives to participate in the study.

\section{CONFLICT OF INTERESTS}

The authors have no financial or any other type of conflicts related to the contents of this manuscript.

\section{ACKNOWLEDGEMENTS}

The authors acknowledge the support received by the Center for Nutrition and Health Research of the INSP, through the project "School and Community Intervention to Prevent Childhood Obesity in Schoolchildren, Tlaltizapán, Morelos" leaded by Dr. Juan A. Rivera Dommarco and financed by Tresmontes Lucchetti México. We wish to thank Dr. Gladys Faba Beaumont at the Center for Information on Public Health Decisions, INSP, and Mrs. Alma Ramos Moreno, Medical Excellence \& Scientific Publications Manager at Sanofi Pharmaceuticals, for their feedback in the initial version of the manuscript. In addition, we thank Oddet Palacios and Tamara Vargas for the collection of the social network data. 


\section{REFERENCES}

1. Lee IM, Shiroma EJ, Lobelo F, Puska P, Blair SN, Katzmarzyk PT. Effect of physical inactivity on major non-communicable diseases worldwide: an analysis of burden of disease and life expectancy. Lancet. 2012; 380(9838): 219-229. DOI: http:// dx.doi.org/10.1016/S0140-6736(12)61031-9.

2. World Cancer Research Found. Food, nutrition, physical activity and the prevention of cancer: a global perspective. Washington, DC: American Institute for Cancer Research; 2007.

3. Powell K, Wilcox J, Clonan A, Bissell P, Preston $\mathrm{L}$, Peacock M, et al. The role of social networks in the development of overweight and obesity among adults: a scoping review. BMC Public Health. 2015; 15: 996. DOI: 10.1186/s12889-015-2314-0.

4. Seidell JC, Halberstadt J. The global burden of obesity and the challenges of prevention. Ann Nutr Metab. 2015; 66(Suppl 2): S7-S12. DOI: $10.1159 / 000375143$.

5. Rivera-Dommarco JA, González de Cossío T, Pedraza LS, Aburto TC, Sánchez-Pimienta TG, Martorell R. Childhood and adolescent overweight and obesity in Latin America: a systematic review. Lancet. 2014; 2(4): 321-332. DOI: http://dx.doi. org/10.1016/S2213-8587(13)70173-6.

6. Rivera-Dommarco JA, Hernández-Ávila M, AguilarSalinas CA. Vadillo-Ortega F, Murayama-Rendón $\mathrm{C}$ (eds). Obesidad en México: recomendaciones para una política de estado. México: Universidad Autónoma de México; 2012: 237.

7. Organización Mundial de la Salud. Recomendaciones mundiales sobre actividad física para la salud. Suiza: Organización Mundial de la Salud; 2010.

8. Grossetti M. ¿Qué es una relación social? Un conjunto de mediaciones diádicas. Rev Hisp Anal Redes Social. 2009; 16(2): 92-127.

9. Shin HS, Valente TW, Riggs NR, Huh J, SprujitMetz D, Chou CP, et al. The interaction of social networks and child obesity prevention program effects: the pathways trial. Obesity. 2014; 22(6): 1520-1526. DOI: 10.1002/oby.20731.

10. Rodríguez J, Mérida F. Guía práctica de redes sociales UCINET 6. Barcelona, España: Universitat de Barcelona, Departamento de sociología y análisis de las organizaciones; 2005 ; p.8-16.

11. Lozares C, Verd J. De la homofilia a la cohesión social y viceversa. Rev Hisp Anal Redes Social. 2011; 20(2): 20-50.

12. Molina J, Quiroga A, Martí J, Maya I, de Federico A (Eds.). Talleres de autoformación con programas informáticos de análisis de redes sociales. Barcelona,
España: Servei de Publicacions Universitat Autónoma de Barcelona; 2006: 34.

13. Macdonald-Wallis K, Jago R, Page AS, Brockman $\mathrm{R}$, Thompson JL. School-based friendship networks and children's physical activity: a spatial analytical approach. Soc Sci Med. 2011; 73(1): 6-12. DOI: 10.1016/j.socscimed.2011.04.018.

14. Ueshima K, Fujiwara T, Takao S, Suzuki E, Iwase T, Doi H, et al. Does social capital promote physical activity? A population based study in Japan. PLoS ONE. 2010; 5(8): 12135.

15. Cox L, Berends V, Sallis J, St John J, Mcneil B, Gonzalez M, et al. Engaging school governance leaders to influence physical activity policies. J Phys Act Health. 2011; 8(Suppl 1): S40-S8.

16. Sawka KJ, McCormack GR, Nettel-Aguirre A, Hawe P, Doyle-Baker PK. Friendship networks and physical activity and sedentary behavior among youth: a systematized review. Int J Behav Nutr Phys. Act 2013; 10(1): 130. DOI: 10.1186/14795868-10-130.

17. Sawka KJ, McCormack GR, Nettel-Aguirre A, Anita Blackstaffe A, Perry R, Hawe P. Associations between aspects of friendship networks, physical activity, and sedentary behaviour among adolescents. J Obes. 2014: 1-12. DOI: http://dx.doi. org/10.1155/2014/632689.

18. De la Haye K, Robins G, Mohr P, Wilson C. How physical activity shapes, and is shaped by, adolescent friendships. Soc Sci Med. 2011; 73(5): 719-728. DOI: 10.1016/j.socscimed.2011.06.023.

19. De la Haye K, Robins G, Mohr P, Wilson C. Obesity-related behaviors in adolescent friendship networks. Soc Networks. 2010; 32: 161-167. DOI: http://dx.doi.org/10.1016/j.socnet.2009.09.001.

20. Valente TW, Fujimoto K, Chou CP, Spruijt-Metz D. Adolescents affiliations and adiposity: A social network analysis of friendship and obesity. J Adolesc Health. 2009; 45(2): 202-204.

21. Arias-Ramos N, Marqués-Sánchez MP, CalvoSánchez MD, Sánchez-García AB, Quiroga-Sánchez E, García-López RM. La red social del adolescente: la influencia de la amistad en el desarrollo de hábitos obesogénicos. Enf Glob. 2015; 38: 263-271.

22. Gesell S, Reynolds E, Ip EH, Fenlason L, Pont $\mathrm{S}$, Poe E, et al. Social influences on self-reported physical activity in overweight Latino children. Clin Pediatr. 2008; 47(8): 797-802. DOI: 10.1177/0009922808318340.

23. Heath GW, Parra DC, Sarmiento OL, Andersen LB, Owen N, Goenka S, et al. Evidence-based intervention in physical activity: lessons from around the world. Lancet. 2012; 38(9838): 272-281. 
DOI: 10.1016/S0140-6736(12)60816-2.

24. Secretaría de Educación Pública. Sistema nacional de información de escuelas. México. Secretaría de Educación Pública; 2010.

25. Patton MQ. Qualitative evaluation and research methods. 3th Edition. Newbury Park, California. EUA: Sage Publications, 2002: 169-183.

26. Habitch JP. Estandarización de métodos epidemiológicos cuantitativos sobre el terreno. Bol Oficina Sanit Panam. 1974; 76(5): 375-384.

27. Wasserman S, Faust K. Social networks analysis: Methods and applications. Cambridge, United Kingdom: Cambridge University Press; 1999: p.33-35.

28. Hanneman RA, Riddle M. Introduction to social network methods. Riverside, California: University of California, Riverside; 2005.

29. WHO Multicentre Growth Reference Study Group. WHO child growth standards: Length/height-forage, weight-for-age, weight-for-length, weight-forheight and body mass index-for-age: Methods and development. Geneva: World Health Organization; 2006.

30. Tudor-Locke, Craig CL, Beets MW, Belton S, Cardon GM, Duncan S, et al. How many steps/day are enough? for children and adolescents. Int J Behav Nutr Phys Act. 2011; 8: 78. DOI: 10.1186/14795868-8-78.

31. Golbeck J, Mutton P. Spring-embedded graphs for semantic visualization. In: Visualizing the semantic web: XML-based internet and information visualization. 2nd Edition. London: Springer Verlag; 2005: p.172-182.

32. Coppinger T, Jeanes Y, Dabinett J, Vögele C, Reeves S. Physical activity and dietary intake of children aged 9-11 years and the influence of peers on these behaviours: a 1-year follow-up. Eur J Clin Nutr. 2010; 64(8): 776-781. DOI: 10.1038/ejen.2010.63.

33. Macdonald-Wallis K, Jago R, Sterne JA. Social network analysis of childhood and youth physical activity. Am J Prev Med. 2012; 43(6): 636-642. DOI: 10.1016/j.amepre.2012.08.021.

34. Sharpe E, Forrester S, Mandigo J. Engaging community providers to create more active afterschool environments: Results from the Ontario CATCH kids club implementation project. J Phys Act Health. 2011; 8(Suppl 1): S26-S31.

35. Hill G, Cleven B. A comparison of 9th grade male and female physical education activities and preferences and support for coeducational groupings. Phys Educator. 2005; 62(4): 187-197.

36. Secretaría de Educación Pública, Secretaría de Salud. Acuerdo nacional para la salud alimentaria estrategia contra el sobrepeso y la obesidad. Programa de acción en el contexto escolar. México: Secretaría de Educación Pública, Secretaría de Salud; 2010.

37. Panter JR, Jones AP, Van Slujis E, Griffin SJ. Neighborhood, route, and school environments and children's active commuting. Am J Prev Med. 2010; 28(3): 268-278. DOI: 10.1016/j. amepre.2009.10.040.

38. Murtagh E, Murphy M. Active travel to school and physical activity levels of Irish primary schoolchildren. Pediatr Exerc Sci. 2011; 23(2): 230-236.

39. Ridgers N, Salmon J, Parrish AM, Stanley R, Okely A. Physical activity during school recess: a systematic review. Am J Prev Med. 2012; 43(3): 320-328. DOI: 10.1016/j.amepre.2012.05.019.

40. Gauthier A, Thirkill K, Dorman S. Examining school-based pedometer step counts among children in grades 3 to 6 using different timetables. J Sch Health. 2012; 82(7): 311-317. doi: 10.1111/j.17461561.2012.00704.x.

41. Jacobi D, Caille A, Borys J, Lommez A, Couet C, Charles $\mathrm{M}$ et al. Parent-offspring correlations in pedometer-assesed physical activity. Plos One. 2011; 6(12): 1-6.

42. D'Haese S, Cardon G, De Bourdeaudhuij I, Deforche B, De Meester F, Van Dyck D. Changes in individual and social environmental characteristics in relation to changes in physical activity: a longitudinal study from primary to secondary school. Int J Behav Med. 2016: 1-14. DOI: 10.1007/s12529-016-9545-z.

43. Lawlor DA, Howe LD, Anderson EL, Kipping RR, Campbell R, Wells S, et al. The Active For Life Year 5 (AFLY5) school-based cluster randomized controlled trial: effect on potential mediators. BMC Public Health. 2016; 16(1): 68-79. DOI: 10.1186/ s12889-016-2734-5.

44. Kriemler S, Meyer U, Martin E, Van Slujis E, Andersen LB, Martin BW. Effect of school-based interventions on physical activity and fitness in children and adolescents: a review of reviews and systematic update. Br J Sports Med. 2011; 45: 923930. DOI: 10.1136/bjsports-2011-090186.

45. Secretaría de Salud. Evaluación de indicadores de servicios del programa entornos y comunidades saludables 2007-2008. México: Secretaría de Salud; 2009: 66 . 